\title{
Impact of Macroeconomic Variables on Economic Development of Bangladesh Since Liberation War: An Empirical Study
}

\author{
Raad Mozib Lalon ${ }^{1}$, Nusrat Jahan ${ }^{2}$ \\ ${ }^{1}$ Department of Banking \& Insurance, University of Dhaka, Dhaka, Bangladesh \\ ${ }^{2}$ Department of Business Administration, Uttara University, Dhaka, Bangladesh \\ Email address: \\ Lalon.banking@gmail.com (R. M. Lalon), Jn.nusrat@gmail.com (N. Jahan)
}

\section{To cite this article:}

Raad Mozib Lalon, Nusrat Jahan. Impact of Macroeconomic Variables on Economic Development of Bangladesh Since Liberation War: An Empirical Study. International Journal of Economics, Finance and Management Sciences. Vol. 3, No. 3, 2015, pp. 179-193.

doi: $10.11648 /$ j.ijefm.20150303.15

\begin{abstract}
The devastating economic situation after liberation war of Bangladesh in 1971 can again be transpired during the current as well as future democratic rulers as the state of the economic condition is currently facing possibly the most severe exigency since the macro-economic crisis of the late 1980s. The twin shocks emanating from the yawning fiscal deficit and deteriorating balance of payments have exposed the entrenched vulnerabilities of the Bangladesh economy, putting under threat the achievement of the 1990s. A large part of these stresses and strains are underpinned by the fundamental structural weaknesses which characterize the Bangladesh economy. But the pressures have been accentuated by a benign neglect in undertaking necessary reform measures to improve the competitiveness of the economy. Bangladesh is a developing country in the South Asia. Its illiterate and unskilled large population is a burden to the country. Agriculture is the main source of the income of the country. Government of the country is taking various steps to decrease poverty, but yet about one-third of people of Bangladesh are living below the national poverty line. More than half of the children of Bangladesh are underweight. The gross domestic product (GDP) is hovering around 6\% for the last decade. Migrated labor and send remittances were on the increase. Conversely, inflation, government debt and GDP growth are nothing to write home about. Shortage of electricity and gas supplies, poor road network, bridges and ports, political unrest and natural calamities are major problems in national production and economic development. Debt burden of the government is increasing rapidly over time due to increase in the budget deficit. Both the internal and external debts of the government are increasing every year. Among the various obstacles, Bangladesh is advocating for poverty reduction by means of improving the quality of education and promoting gender equality. This has led to an achievement of reduction in child mortality and improvement in maternal health.
\end{abstract}

Keywords: Capital Market, Deficit Financing, Development and Non-Development Expenditures, GDP, Inflation, Remittance

\section{Introduction}

According to the gradation by the International Monetary Fund, Bangladesh ranked as the 48th largest economy in the world in 2008, with a gross domestic product of US\$224,889 million. The economy has grown at the rate of $6-7 \%$ p.a. over the past few years. While more than half of the GDP belongs to the service sector, nearly two-thirds of Bangladeshis are employed in the agriculture sector, with rice as the singlemost-important produce. In 2013, its population increased to more than 160 million. The population density of Bangladesh is about $1,082 / \mathrm{km}$, which is the highest in Southern Asia.
About $77 \%$ of the population lives in the rural areas. Agriculture is the backbone of the economy. Thus, about $80 \%$ of the population is agrarian. Bangladesh is the twelfth-poorest country in the world and the poorest in Southern Asia. More than half of the children of Bangladesh are underweight, which is obviously the malnutrition of the future generation. According to the latest Household Income and Expenditure Survey, HIES (2010), about one-third of people of Bangladesh are living below the national poverty line. Although global economy is facing difficulties, economic growth in Bangladesh is projected at close to 6\% in FY 2013. In Bangladesh, the real gross domestic product (GDP) was projected to grow at about 
$6.2 \%$ in FY 2011, up from 5.8\% FY 2010. In fiscal year 20122013, the average exchange rate of Bangladeshi currency taka against US dollar is 80.00 than that of 81.00 in FY 2011-2012. By the end of February 2011, broad money had risen by $21.7 \%$ and reserve money by $20.8 \%$ over February 2010 . Broad money rose due to the growth in net domestic assets, such as credit to the private sector, which grew by $28.3 \%$ and credit to non-financial public sector entities, which grew by $38 \%$. The price hike of food, expenditure for fuel oil, import of machineries for establishing new electricity plant and import of fuel for producing electricity, etc. depreciate the Bangladesh currency against US dollar. In 2010-2011, receipt of net foreign aid is $\$ 1,049.63$ million, and the net foreign direct investment is $\$ 768$ million and the total amount of remittance receipt is $\$ 11,650.32$ million. Hence the foreign aid is very low compared to the percentage share of remittance in GDP. It is expected that the net foreign aid and flow of remittance in FY 2014-2015 might reach \$1,066.69 million and \$15,309.996 million respectively. Bangladesh is on-track to meet the Millennium Development Goals (MDGs) on poverty, education and gender equality, and has attained substantial reductions in child mortality and improvements in maternal health. Debt burden is increasing rapidly over time due to increase in the budget deficit. Both the internal and external debts of the government are increasing every year. In Bangladesh, during 2000 to 2005, income poverty reduced from 48.9 to $40 \%$ and 2005 to 2010 reduced from 40 to $31.50 \%$. The present government has targeted to reduce poverty rate to 25 and $15 \%$ by 2013 and 2021, respectively. Various microfinance programs also help the poor to reduce the poverty of the country. Here the purpose is to explore the economy of our country since liberation. Let's start the journey.

\section{Objective of the Study}

The main objective of the study is to evaluate food insecurity, health, education and economic situation of the citizens of the country. Our aim is also to show the obstacles of the development of the country and direction to the future development.

\section{Methodology}

We have prepared the paper on the basis of data from various sources of Bangladesh and with the practical experience of the economic development of the country. In the last decade economy, healthcare services and education have increased but the political unrest remains unchanged, which is a hindrance in the advancement of the country. Poverty and illiteracy are also two other major problems in the economic progress of the country. In this paper, we have stressed on the inflation, debt burden, social safety net programs and collapse of the capital market. We also show the economic development of the country due to the creative activities of the government of Bangladesh and various nongovernment organizations (NGOs).

\subsection{Food and Hunger in Bangladesh}

During the independence in 1971, Aman was the major food crop, which was the dominant source of total rice production. At present, Aman rice occupies 50\% of total rice area and contributes $38 \%$ of total production, Boro contributes about $41 \%$ of total rice area and contributes $56 \%$ of total rice production in Bangladesh and Aus rice supplies about $9 \%$ of total rice area and $6 \%$ of rice production. Rice is the staple food of Bangladesh and among the $94 \%$ of all food grains produced annually is rice. During the last decade production of rice has remarkably increased, vegetable production was almost doubled, potato production increase 2.5 fold, fish production has increased due to increase in inland fishery, meat production has increased, superseding the rate of increase in population, egg and milk production also has increased in parallel. On the other hand, total production of pulses (one of the major sources of protein for the poor), oilseeds and fruits has gone down. In Bangladesh, per capita average calorie intake per day is $2,238.5$, of which $75 \%$ of the energy intake comes from cereals. Using the conversion factor of $3.57 \mathrm{Kcal} / \mathrm{gm}$, the daily domestic food grain requirement can be calculated as:

Daily food per capita grain requirement $=(75 \%$ $2238.5) / 3.57=470.3 \mathrm{gm} /$ capita/day.

It can be used to calculate the annual food grain requirement and food gap in the country. Annual food grain requirement in $2013=$ Population $\times 470.3 \times 365$ days $=(160$ $470.3365) / 1000000=27.5 \mathrm{mMT}$.

Food gap $=$ Requirement - Domestic production.

In 2007, domestic production was 28.06 million metric ton (mMT) and total food grain requirement was $24.14 \mathrm{mMT}$.

In 2007, food gap $=24.14-28.06=-3.92 \mathrm{mMT}$.

Although there is food gap every year and more than 60 million people remain hungry everyday due to food gap, the government figures do not show any food gap in the country. In Bangladesh, the government has less control over the market and the market is mainly controlled by the traders, hoarders and business syndicates.

The price hike for agricultural commodities, particularly rice and wheat in 2007 and 2008, has posed a major challenge to food security in Bangladesh. In Bangladesh, food prices are increased by $72 \%$ over a period of only 10 months from June 2007 to April 2008 at the backdrop of global food prices hike. This rising inflation has become an alarming threat to the poor and middle class people from all segments of the society. The price that drastically increased in 2007 had faced a downward trend after June 2008, but from 2009 the price has started to rise again (Bangladesh Economic Update, 2011a).

\subsection{Malnutrition of Mothers and Children}

In Bangladesh a large mass of the rural populations still live below the poverty line, heavily undernourished with inadequate access to safe and nutritious food for a healthy life. In 1970s, about 70\% people of Bangladesh were under the food consumption poverty line and at present it is down 
to less than half of the populations but still it is far from being food secure. Food prices were more unstable during the 1974 famine due to severe rice shortages caused by droughtrelated production shortfalls and shortage of foreign exchange for government rice imports. At this time, Bangladesh faces a record of price hike from 9.1 to $108.6 \%$. In Bangladesh, $40 \%$ of the population (64 million) are categorized as absolutely poor, who fail to acquire the minimum level of food energy $2,122 \mathrm{Kcal} /$ day to maintain normal health, 32 million people are categorized as "hardcore poor", who fail to acquire $1,805 \mathrm{Kcal} /$ person/day, and 13 million are "ultra poor", who fail to acquire 1,600 Kcal/person/day (Bangladesh Bureau of Statistics, BBS, 2007). The World Bank (WB), the government of Bangladesh (GOB) and the United Nations (UN) in their respective reports on millennium development goals (MDGs), express the target of $34 \%$ children being underweight as nonattainable at present rates of progress. It is estimated that girls and women are overwhelmingly more malnourished than boys and men. The poverty of Bangladesh is not decreasing due to low income of most of the populations, recurrent natural calamities, increase of population and increasing international prices of food commodities.

\subsection{Social Safety Net Programmes (SSNPS) in Bangladesh}

Food aid from donors is decreasing gradually every year. Hence the government of Bangladesh should take necessary steps to increase food production in future. The government of Bangladesh is trying to reduce poverty by implementing various kinds of SSN programs since its independence in 1971. The government of Bangladesh (GOB) also allocated Tk.17,327 crore (Bangladeshi currency is Taka $=$ Tk. And $\$ 1=$ Tk.80 in 2013) for the SSN in the FY 2009-2010 which is about $15.22 \%$ of total budget outlay, and $2.52 \%$ of GDP respectively, which targeted poor and ultra poor segments of the society to lift out of poverty. In FY 2010- 2011, the allocation for social safety net programs was $2.64 \%$ of GDP.

Bangladesh has a widespread portfolio of both food and cash- based SSNPs. In 2011, about 11.38 million men and 24.05 million women were engaged in social security and social empowerment act. At present there are about 27 such programs, which cover only about $6-7 \%$ of the poor, so that, fund and beneficiaries under this program must be increased.

In Bangladesh infrastructure and construction programs for SSN are Food for Work (FFW) or Rural Development (RD) programs, the Food for Asset Creation (FFA) component of the Integrated Food Security program, and Test Relief (TR) distribute food grains (rice and wheat) as wage payments to workers in labor-intensive public works programs. Both men and women participate in FFW and TR, whereas in FFA at least $70 \%$ of the participants must be women. Only women can participate in Rural Maintenance Program (RMP), which offers cash wages for maintaining rural earthen roads.

The Vulnerable Group Feeding (VGD) program in
Bangladesh is the largest in the world that exclusively targets women. More than 750,000 ultra-poor rural women in the country received support under the VGD Program in 2006. Of the 750,100 women served by VGD, 640,721 women $(85.4 \%)$ and their family members received IncomeGenerating Vulnerable Group Development (IGVGD) support and 109,379 women (14.6\%) and their dependants received support under the Food Security Vulnerable Group Development (FSVGD) component in 2005-2006.

\subsection{Major Economic Problems in Bangladesh}

Bangladesh faces natural disasters such as, devastating floods, cyclone, tornado, storm, draught, earth quake, tidal surge, river bank erosion, salinity expansion in coastal areas, infrastructure collapse, fire, tsunami, arsenic contamination in ground water, Monga (about to famine in north-western part of Bangladesh) which pose multiple threats to the development of the country. Shortage of electricity and gas supplies are major problems in national production and development. So that foreign direct investment (FDI) is comparatively low due to these difficulties. Every government will face various difficulties in the Medium Term Budget Framework (MTBF) from 2013 to 2017. The next problems are poor infrastructure of roads, bridges and ports. Inflation is another problem in the development of the country. Political instability such as, strike of opposition parties is one of the main causes of hindrance of economical improvement.

In Bangladesh export is less than import, which is a permanent problem of the country. Other obstacles of development are illiteracy and unskilled manpower and nonproper utilization of the manpower. Natural calamities and non-planned urbanizations are also effect economic development. External and internal debt and budget deficit in every year influence the economic development.

\subsection{Economic Development of Bangladesh}

In recent years, Bangladesh has experienced high national growth. The rapid expansion of exports in the ready-made garment increased. The Government of Bangladesh has 2011-2015 five-year plan of economic development which prioritizes public and private infrastructure investment, and has set a target of increasing the investment rate to $32 \%$ GDP by 2015 as depicted below by revealing a comprehensive discussion since liberation war:

\subsubsection{Gross Domestic Product (GDP)}

GDP is said to be the key indicator of macro economy. The IMF and World Bank predict GDP growth over the next 5 years will be about $6.5 \%$, well short of the $9-10 \%$ needed to lift Bangladesh to Mid Income Nations. This is a prediction. Now it's time for flash back.

Scenario of 70s: (Growth Rate of GDP) 


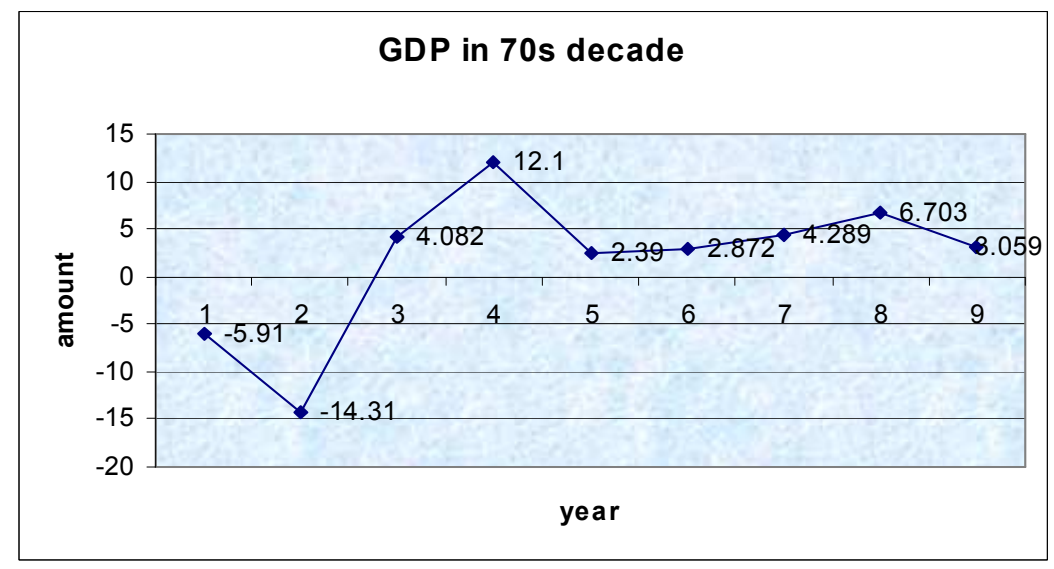

Graph A1. GDP in 70 s.

Graph A1 as well as graph is showing the growth rate of GDP in 70s decade. It was negative in 71 and 72 . War had a devastating effect in our economy. But the situation was recovered because the growth rate tends to increase till 1974 but, in 1975 growth rate of economy declined. This is because of the political instability and famine. In 1977 an increasing trend is observed. But the trend wasn't constant Scenario of 80s: (Growth Rate of GDP)

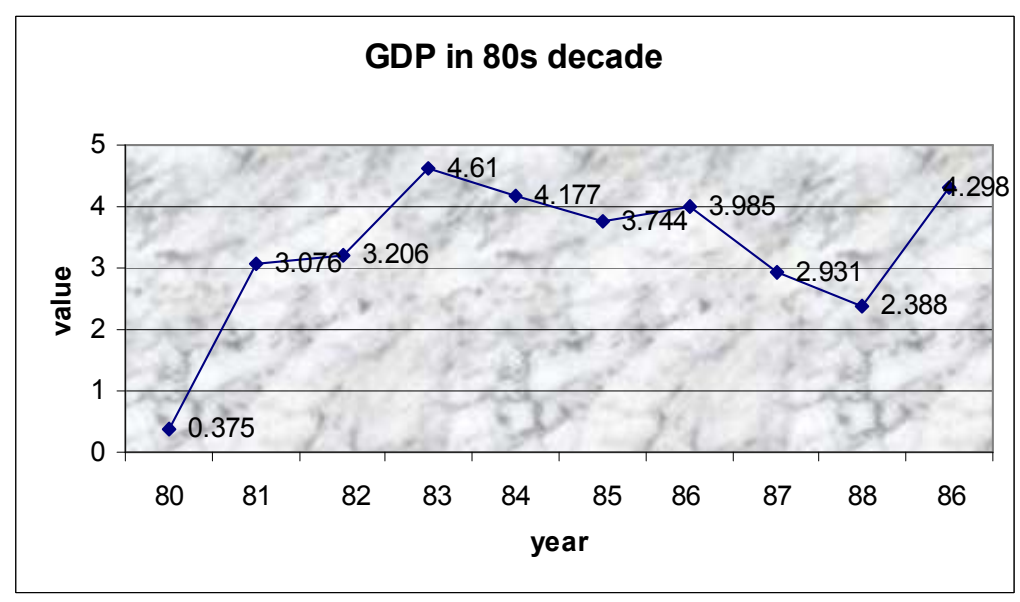

Graph A2. GDP growth in 80 s.

In 80 s decade huge fluctuation is observed, as shown in Graph A2. Growth rate of GDP increased till 1984. But in the next year it declined due to socio-political instability. And it keep on declining till 1988. In 1988 flood affected GDP growth negatively. But the situation was recovered in the next year.

Scenario of 90s: (Growth Rate of GDP)

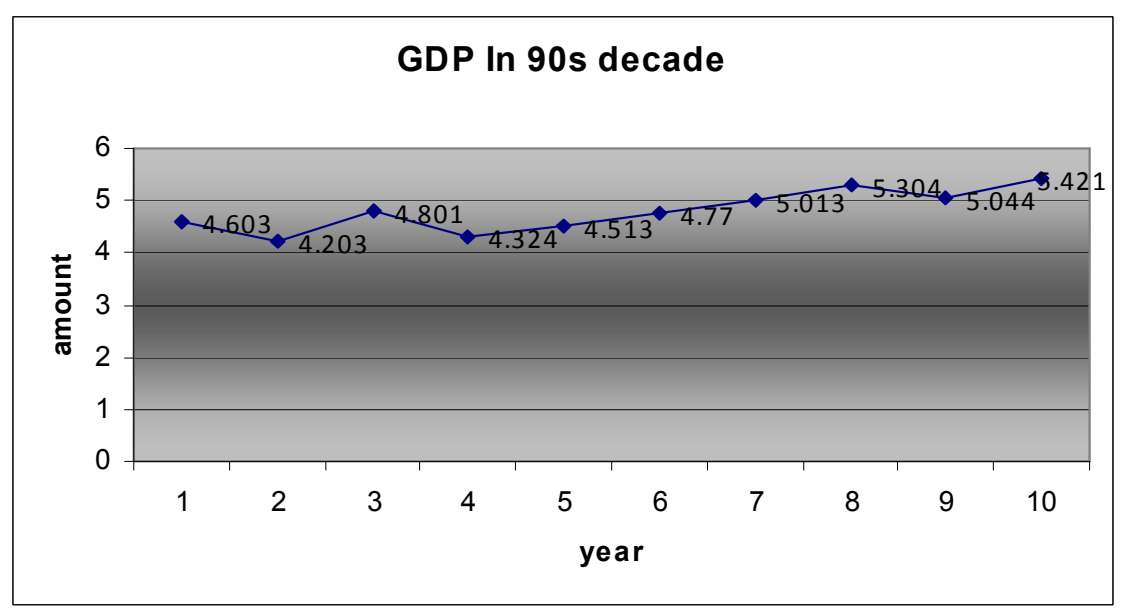

Graph A3. GDP Growth in 90s. 
Graph A3 is showing that GDP growth rate was quite stable in this decade. It increased in an increasing trend from
1996.

Scenario from 2000-Present: (Growth of GDP)

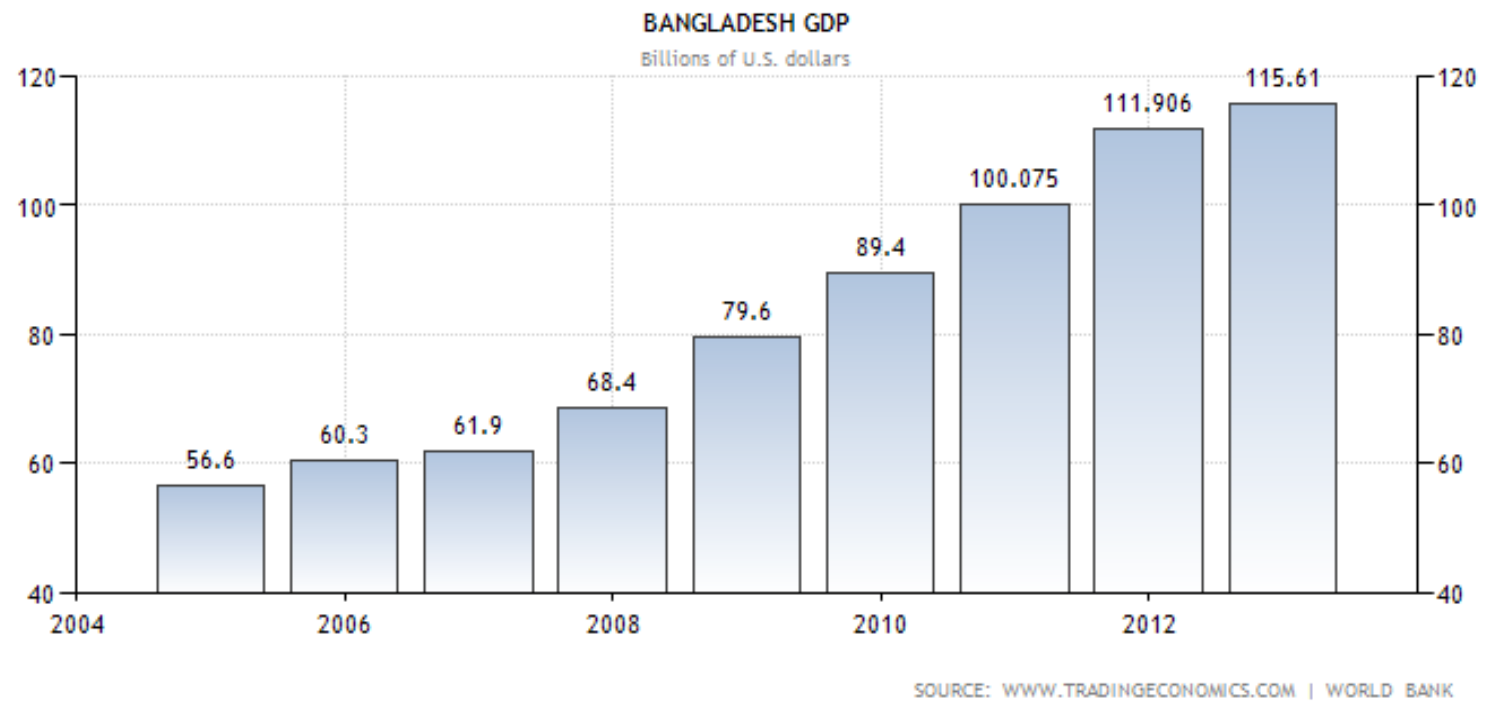

Graph A4. GDP growth from 2004-present.

Interpretation: GDP growth increased in a decreasing trend till 2002. This is because of political instability. Election of 2001 had a negative impact on GDP growth. Then it again started increasing. But in 2009 GDP growth rate declined because of recent global recession.

\subsubsection{Inflation}

Inflation is when prices continue to move stealthily upward, usually as a result of overheated economic growth or too much capital in the market chasing too few opportunities. In other words, inflation is also erosion in the purchasing power of money - a loss of real value in the internal medium of exchange and unit of account in the economy. Here changes in inflation are shown on basis of GDP deflator. Inflation as measured by the annual growth rate of the GDP implicit deflator shows the rate of price change in the economy as a whole. The GDP implicit deflator is the ratio of GDP in current local currency to GDP in constant local currency.

Scenario of 70s: Inflation (Based on GDP deflator)

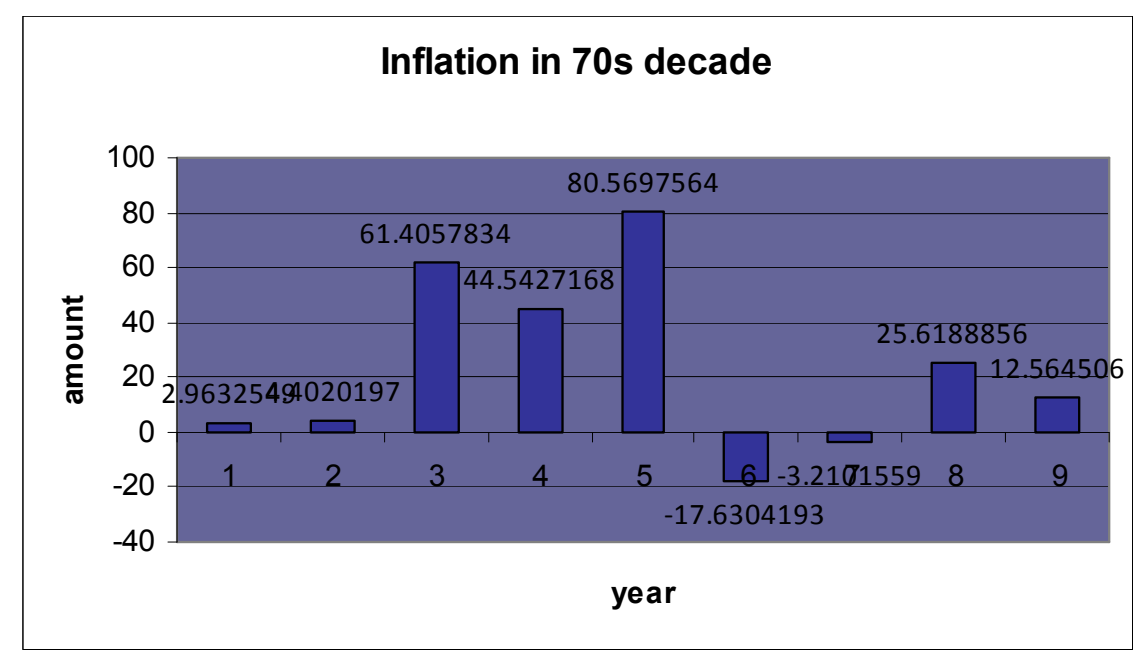

Graph A5. Inflation in 70s.

Graph A6 shows that during the first half of 70 s decade rate of inflation was too high. So it can be said that current market price of GDP was higher than the constant price. This high rise in price level reduced the purchasing power of money. Another reason may be that war had a negative impact on production, so cost of production raised and famine increased the demand for goods.In the second half of 70 s decade inflation became negative which is another extreme. It may be attributed to fluctuations in real demand for goods and services, or changes in available supplies such as during scarcities, as well as to growth in the money supply.

Scenario of 80 s: (Inflation) 


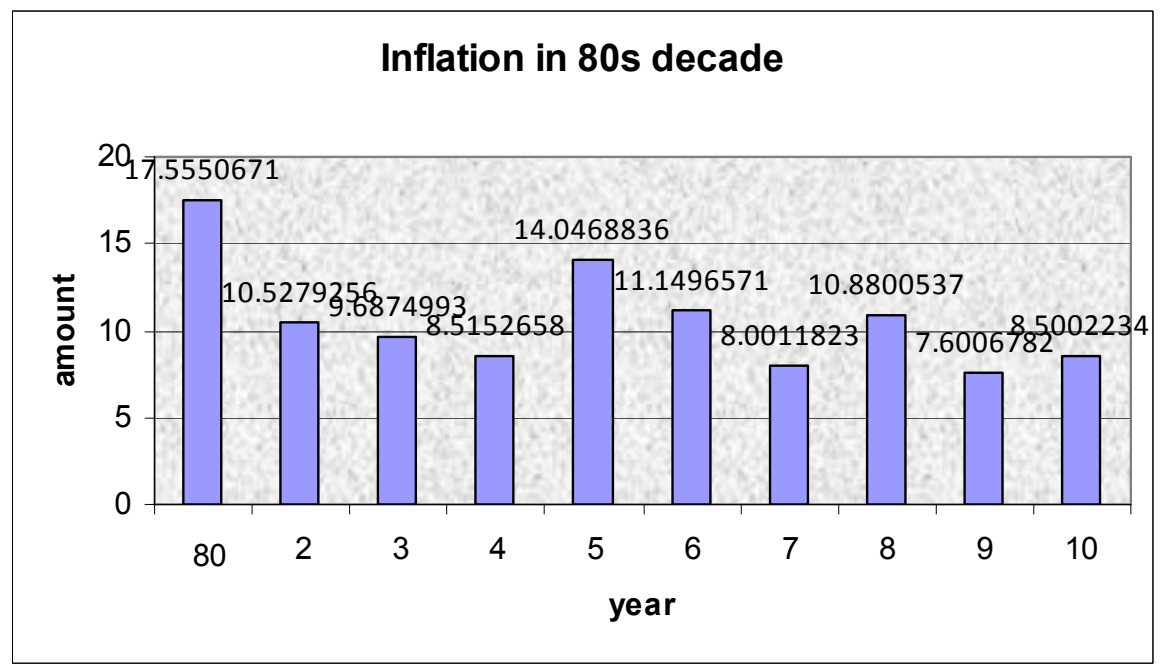

Graph A6. Inflation in 80 s.

Inflation in the first half in 80 s decade seems to decrease until 1983. but in 1984 it raised again. That is price level increased. Demand of goods became too high which resulted in raise in inflation.

In the second half of 80 s decade, average inflation is lower than the first half. Seems that money supply became lower in this sphere compared to the first half. And cost of production was decreased as well.

Scenario of 90s: (Inflation )

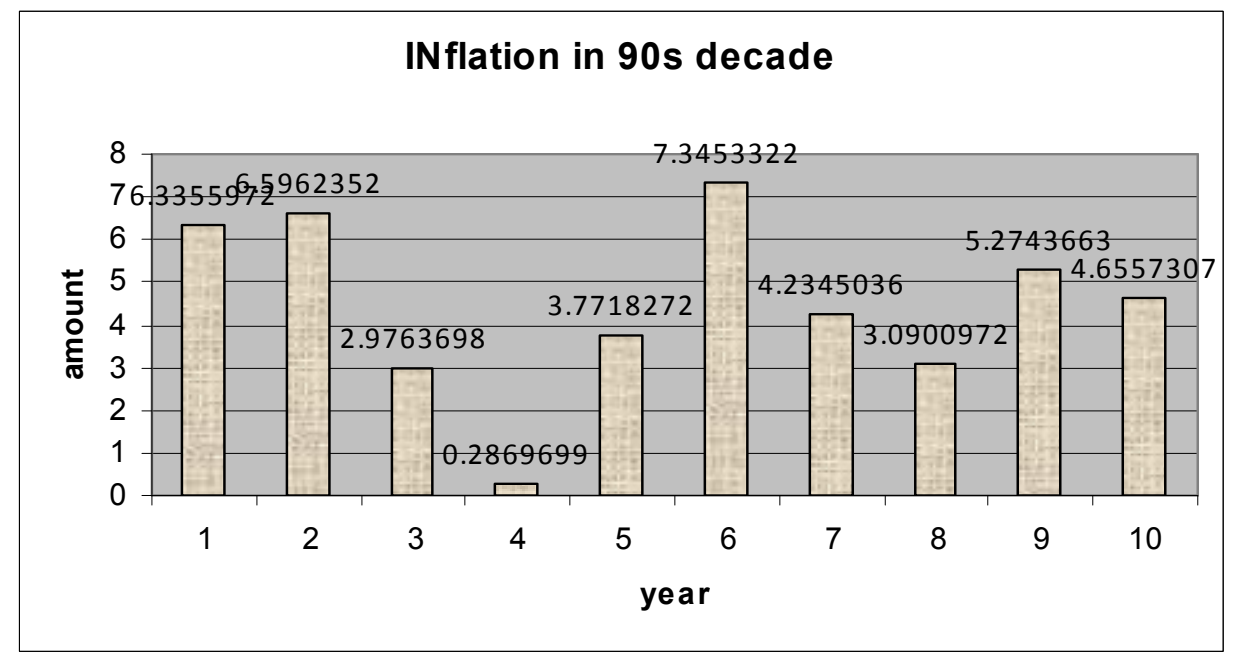

Graph A7. Inflation in 90s.

In the early $1990 \mathrm{~s}$, the average inflation rate was 5.20 percent. Except for the first two years - 7 - during the abovementioned period, inflation rate varied mainly with growth in nominal money supply. Besides money supply growth, a close association of inflation with change in the index of prices of agricultural production and change in the index of prices of industrial production is observed Substantial depreciation in the exchange rate in FY91, higher money supply growth and lower deposit rate in FY95 contributed to the comparatively higher inflation rates in these two years, as shown in Figure 8.
During the second half of 1990s (95-99), average inflation rate was higher in comparison with inflation rates during 9095. The high inflation rates during the three years, 96, 98 and 99 , in particular, contributed to the comparatively higher average inflation during the period. Supply shortages in the rural areas originating from political instability in 96 and disruption due to floods in 1998 caused serious shortfall of food and also hampered all other agricultural production, which ultimately caused higher inflation rates in these three years.

Scenario from 2000-Present: (Inflation) 


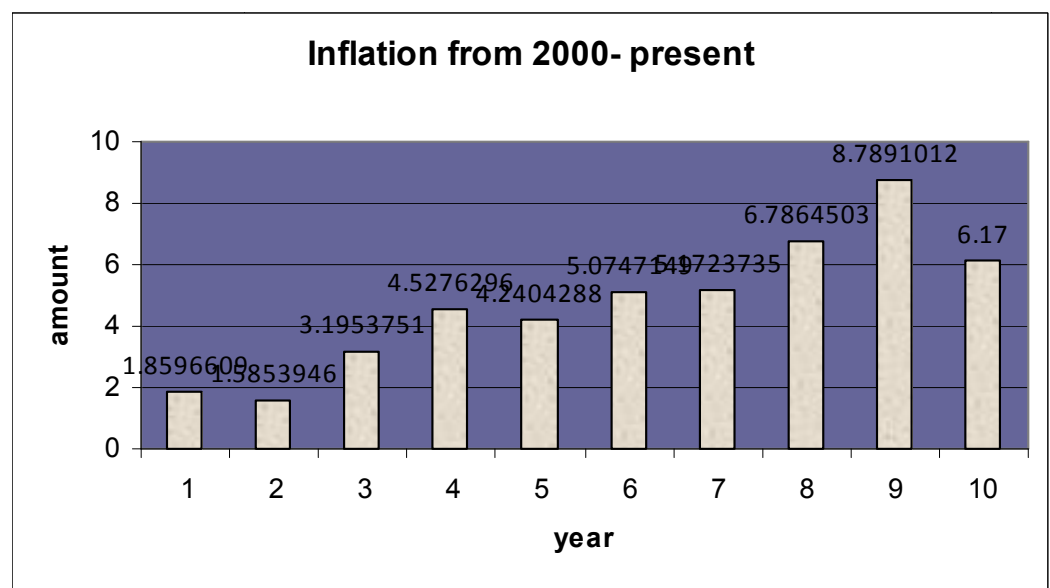

Graph A8. Inflation from 2000-2010.

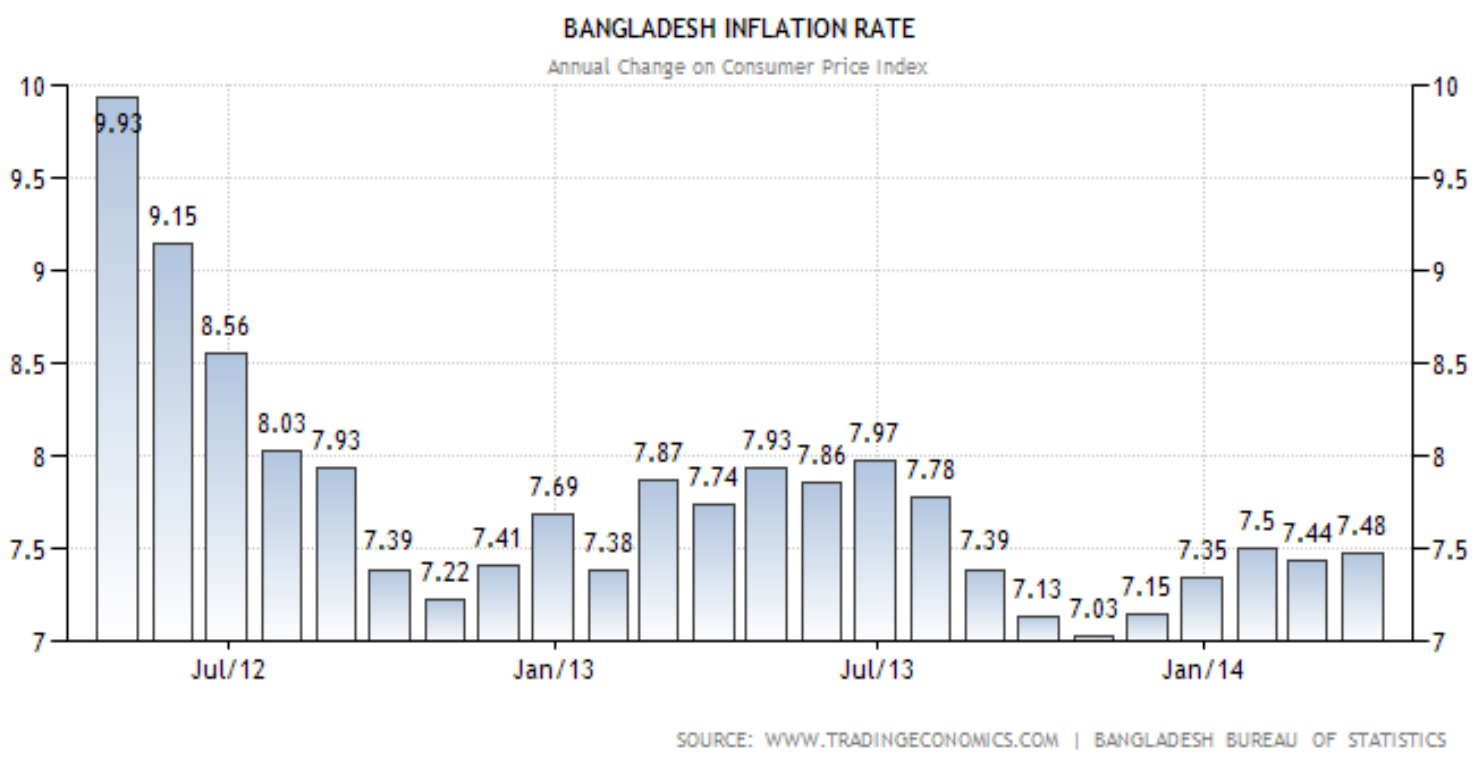

Graph A9. Inflation from 2010-Present.

In this sphere Bangladesh economy experienced comparatively low average inflation rates compared to that in the 1990s, though the trend has been on the up-side. Buffer agricultural production contributed to lower inflation rates in the three successive years following floods. However, inflation accelerated to 4.38 per cent during 03, compared to 2.79 per cent in 02 , and continued to rise and reach at 7.16 per cent in F06. The higher inflation rates during 03-06 and 08 are also associated with higher rates of GDP growth, money supply growth and larger depreciation of the exchange rate, particularly in the last two years. Exchange rate might have played a significant role in causing inflation in this period because of the introduction of flexible exchange rate regime since May 2003. The combination of flexible exchange rate and further integration with the international trade could have adversely affected the prices of imported items, which may explain the overall price index of the country.

\subsubsection{Remittance Flow in Bangladesh}

The remittance is a driver of growth of the economy of a country. It develops volatility in the exchange rates, and plays an important role in the macroeconomic stability. Bangladesh is considered as one of the major labor exporting countries of the world. Since independence over 7.4 million labors went abroad. In FY 2010-2011, flow of remittance increases by $6.03 \%$ over that of previous fiscal year and reaches at $\$ 11.65$ billion while foreign currency reserve increases by only $1.50 \%$ and reaches $\$ 10.91$ billion. It is forecast that in FY 2014- 2015, remittance might reach $\$ 15.31$ billion and foreign currency reserve would reach $\$ 14.64$ billion. Current account balance is not satisfactory in Bangladesh. Remittance plays an important role for a positive current account balance in any economy. Bangladesh is considered as a trade deficit country in the Asia but current account balance since FY 2005-2006 remains positive due to high remittance inflow. In FY 2010-2011, remittance inflow is $\$ 11,650$ million while the trade deficit is $\$ 7,328$ million, service deficit is $\$ 2,398$ million and income deficit is $\$ 1,354$ million and as a result the current account balance in FY 2010-2011 is only $\$ 995$ million. Current account balance in FY 2009-2010 was $\$ 3,724$ million which was high during the 
last decade.

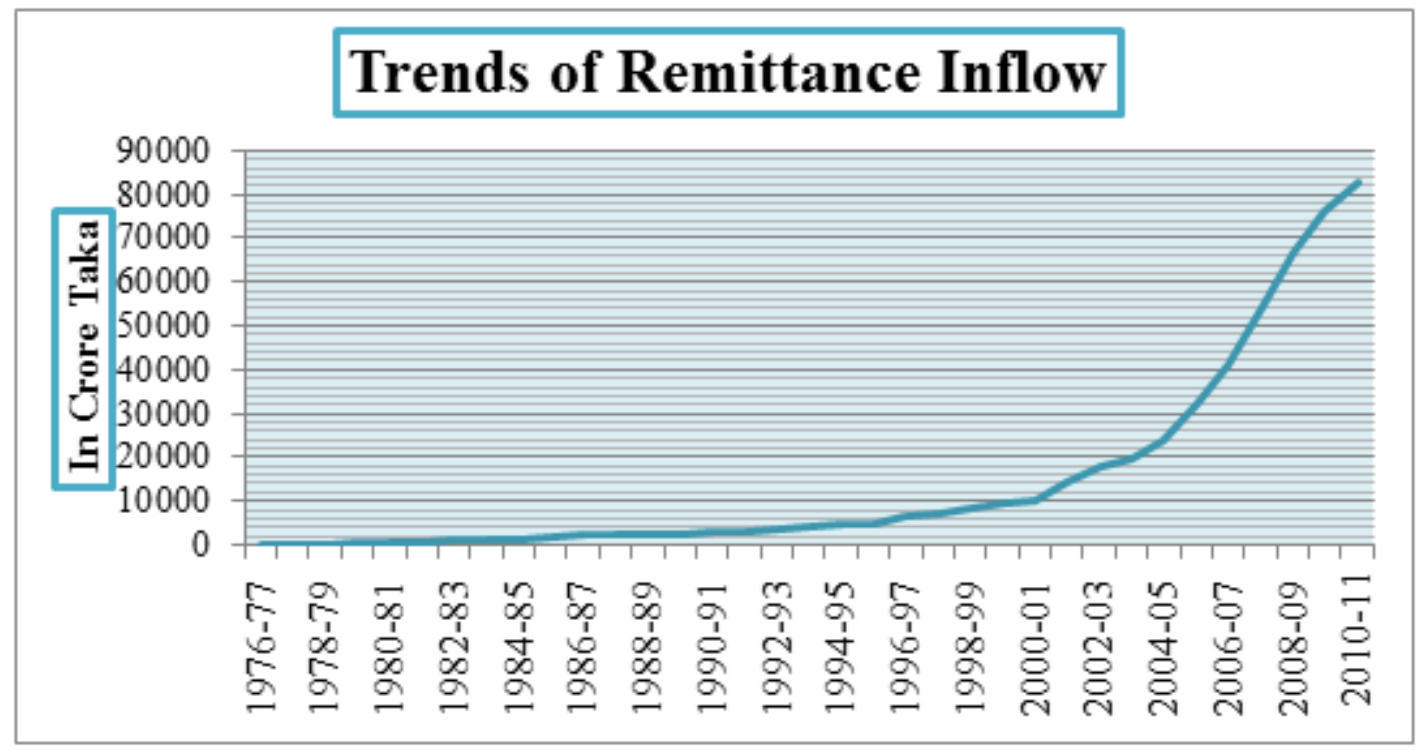

Figure 1. Trends of Remittance Inflow

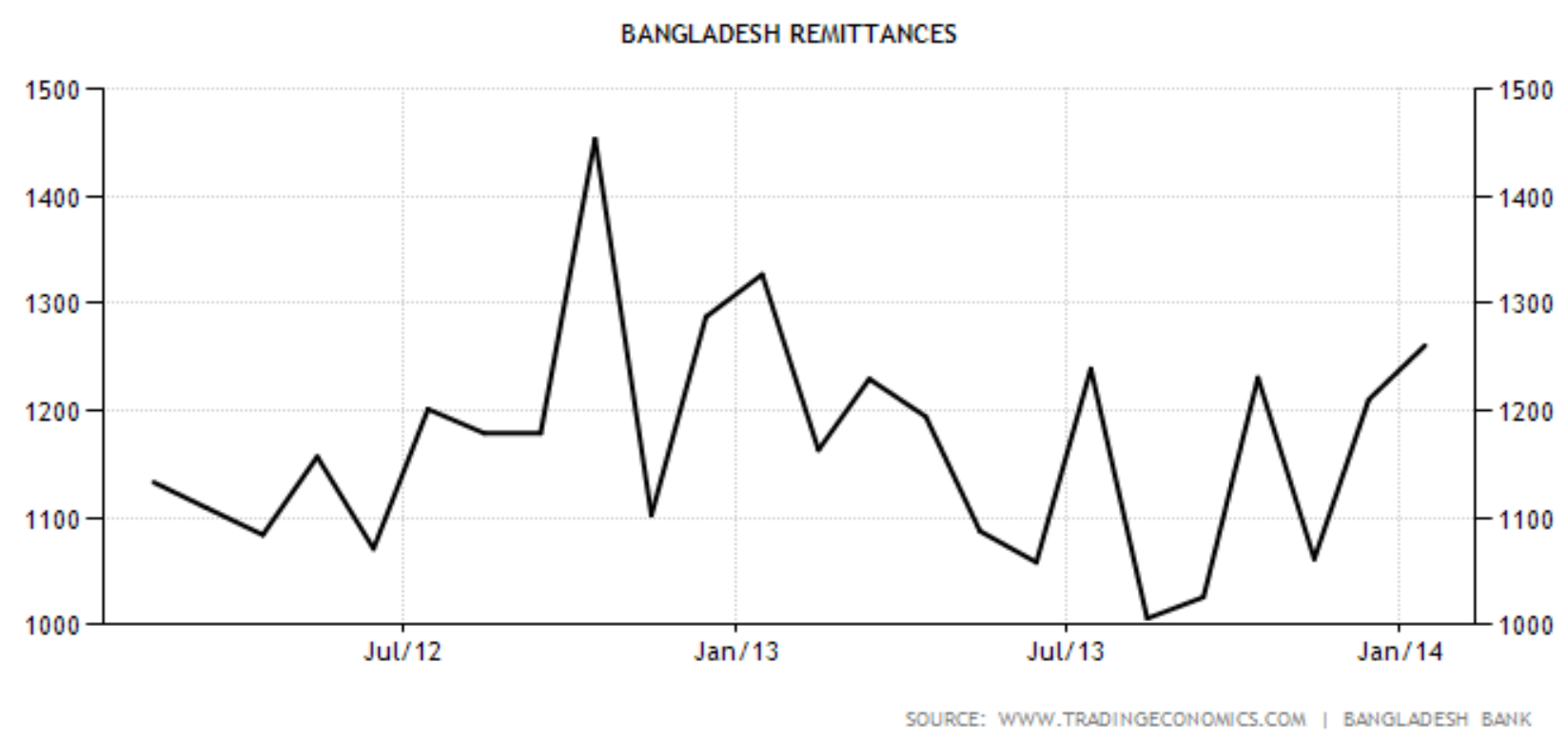

Figure 2. Trends of Remittance Inflow (from 2012- January2014)

The annual flow of remittances received from Bangladeshi migrant workers has been quite robust throughout the 1990s rising from US\$ 764.0 million in FY1991 to US\$ 1949.32 million by FY2000. At the beginning of the new decade after 1990s flow of remittances has been continuing its robust growth and reached to US\$ 3367.0 million in FY04. In FY2007- 08, remittances stood at US\$ 7,914.9 million registering 32.4 percent increase over the previous year. Remittances in March, 2010 stood higher at US\$941.31 million against US\$827.96 million of February 2010.This was also higher by US\$55.64 million against US\$885.67 million of March, 2009. Total remittances receipts during July-March, 2009 - 10 increased by US\$1220.99 million or 17.36 percent to US\$8254.86 million against US\$7033.87 million during July-March, 2008 - 09. Remittances in Bangladesh increased to 1260.66 USD Million in January of 2014 from 1210.21 USD Million in December of 2013. Remittances in Bangladesh averaged 1168.69 USD Million from 2012 until 2014, reaching an all time high of 1453.70 USD Million in October of 2012 and a record low of 1005.80 USD Million in August of 2013. 
Table 1. GDP and remittance as a percentage share of GDP.

\begin{tabular}{llll}
\hline Fiscal year & Remittance(in crore taka) & \% change in remittance & Remittance as \% of GDP \\
\hline $2001-2002$ & 14.377 .03 & 40.17 & 5.26 \\
$2002-2003$ & 17.728 .82 & 23.14 & 5.898 \\
$2003-2004$ & 19.869 .8 & 12.15 & 5.97 \\
$2004-2005$ & 23.646 .97 & 18.99 & 6.38 \\
$2005-2006$ & 32.275 .68 & 36.49 & 7.76 \\
$2006-2007$ & 41.298 .53 & 27.96 & 8.74 \\
$2007-2008$ & 54.295 .14 & 31.45 & 9.95 \\
$2008-2009$ & 66.675 .85 & 22.8 & 10.85 \\
$2009-2010$ & 76.010 .96 & 14.15 & 10.95 \\
$2010-2011$ & 82.992 .89 & 9.04 & 10.54 \\
$2011-2012$ & 89.853 .16 & 8.27 & 9.98 \\
$2012-2013$ & 96.713 .43 & 7.63 & 10.86 \\
$2013-2014$ & 1.03 .573 .70 & 7.09 & 10.99 \\
$2014-2015$ & 1.10 .433 .97 & 6.62 & 11.12 \\
\hline
\end{tabular}

Source Bangladesh Economic Update (2011c)

\subsubsection{Foreign Exchange Reserve}

The gross foreign exchange reserve is getting increased at every interval of decades since liberation war in the economy of Bangladesh. Foreign Exchange Reserves are the foreign assets held or controlled by the country central bank. The reserves are made of gold or a specific currency. They can also be special drawing rights and marketable securities denominated in foreign currencies like treasury bills, government bonds, corporate bonds and equities and foreign currency loans. From 1981 to 1990, the Fx reserve was not significant due to lack of efforts taken by autocratic Govt in order to flourish foreign exchange business. Rather, it starts increasing the reserve of foreign currency as the domestic govt commenced their initiatives towards the development of Fx Business since 1991 as shown below:

\section{BANGLADESH FOREIGN EXCHANGE RESERVES}

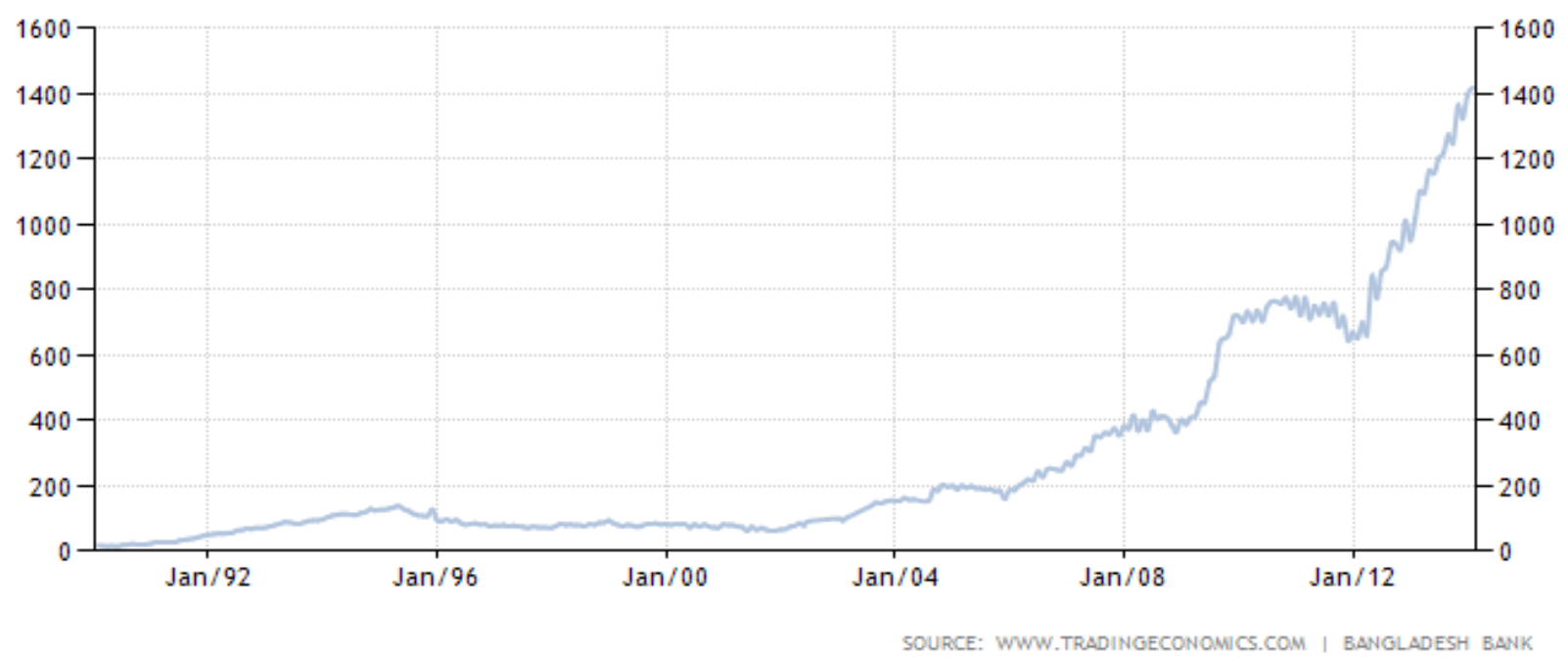

Figure 3. Foreign Exchange reserve of Bangladesh

Foreign Exchange Reserves in Bangladesh increased to 1417.64 BDT Billion in January of 2014 from 1395.18 BDT Billion in December of 2013. Foreign Exchange Reserves in Bangladesh is reported by the Bangladesh Bank. Foreign Exchange Reserves in Bangladesh averaged 281.34 BDT Billion from 1990 until 2014, reaching an all time high of 1417.64 BDT Billion in January of 2014 and a record low of
13.75 BDT Billion in May of 1990. In Bangladesh,

\subsubsection{Trends of Import}

Bangladesh imports mostly petroleum product and oil, machinery and parts, soybean and palm oil, raw cotton, iron and steel and wheat. Bangladesh main imports partners are China (17\% of total), India, Indonesia, Singapore and Japan. 
Imports in Bangladesh increased to 2976.90 USD Million in September of 2012 from 2317 USD Million in August of 2012. Imports in Bangladesh were reported by the Bangladesh Bank. Historically, from 1995 until 2012, Bangladesh Imports averaged 4665.54 USD Million reaching an all time high of 20291.40 USD Million in June of 2009 and a record low of 1424.20 USD Million in August of 2009. Total import payments of Bangladesh (including EPZ) during the quarter July-Sept'2013 stood at Tk 758402 million (or US\$ 9753.7 million) as compared to Tk 680976 million (or US\$ 8740.1 million) for the quarter April-June'2013.

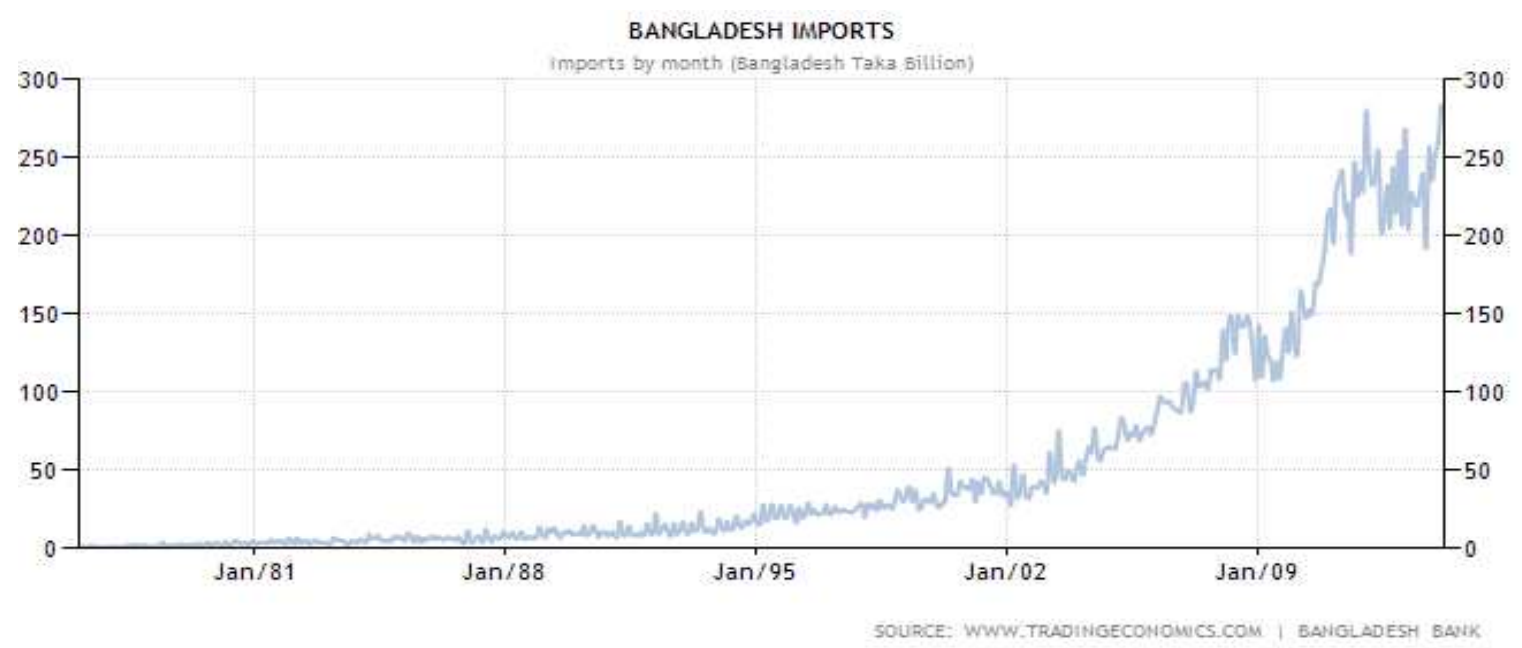

Fig ure 4. Trends of Import

BANGLADESH IMPORTS

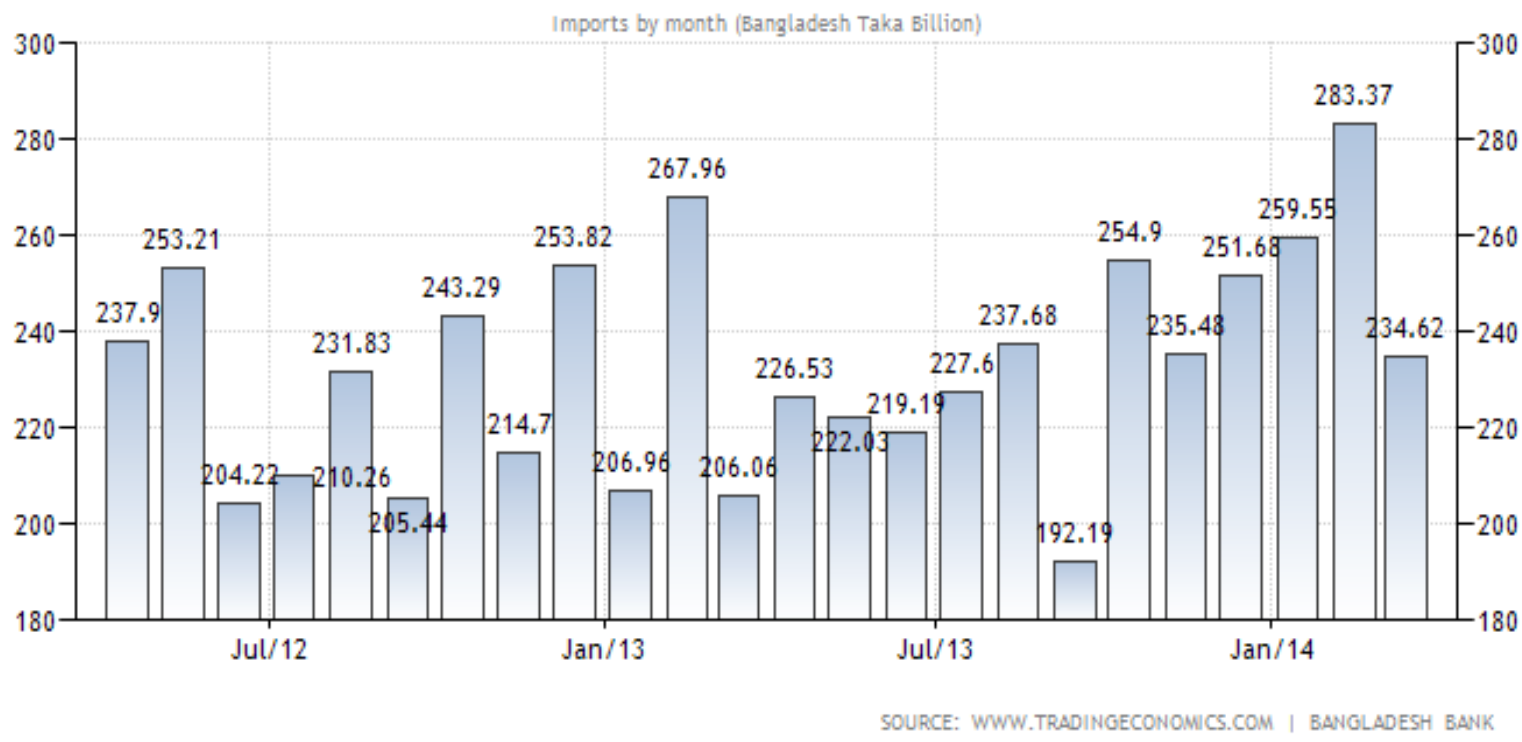

Fig ure 5. Trends of Import (from 2012-January 2014)

\subsubsection{Trends of Export}

Bangladesh's' main exports partners are United States $(23 \%$ of total), Germany, United Kingdom, France, Japan and India. Bangladesh exports mainly readymade garments including knit wear and hosiery ( $75 \%$ of exports revenue). Others include: Shrimps, jute goods (including Carpet), leather goods and tea. Exports in Bangladesh increased to 180.06
Bangladesh Taka Billion in February of 2014 from 163.02 Bangladesh Taka Billion in January of 2014. Exports in Bangladesh are reported by the Bangladesh Bank. Exports in Bangladesh averaged 27.81 Bangladesh Taka Billion from 1972 until 2014, reaching an all time high of 189.84 Bangladesh Taka Billion in October of 2013 and a record low of 0.05 Bangladesh Taka Billion in February of 1972. 


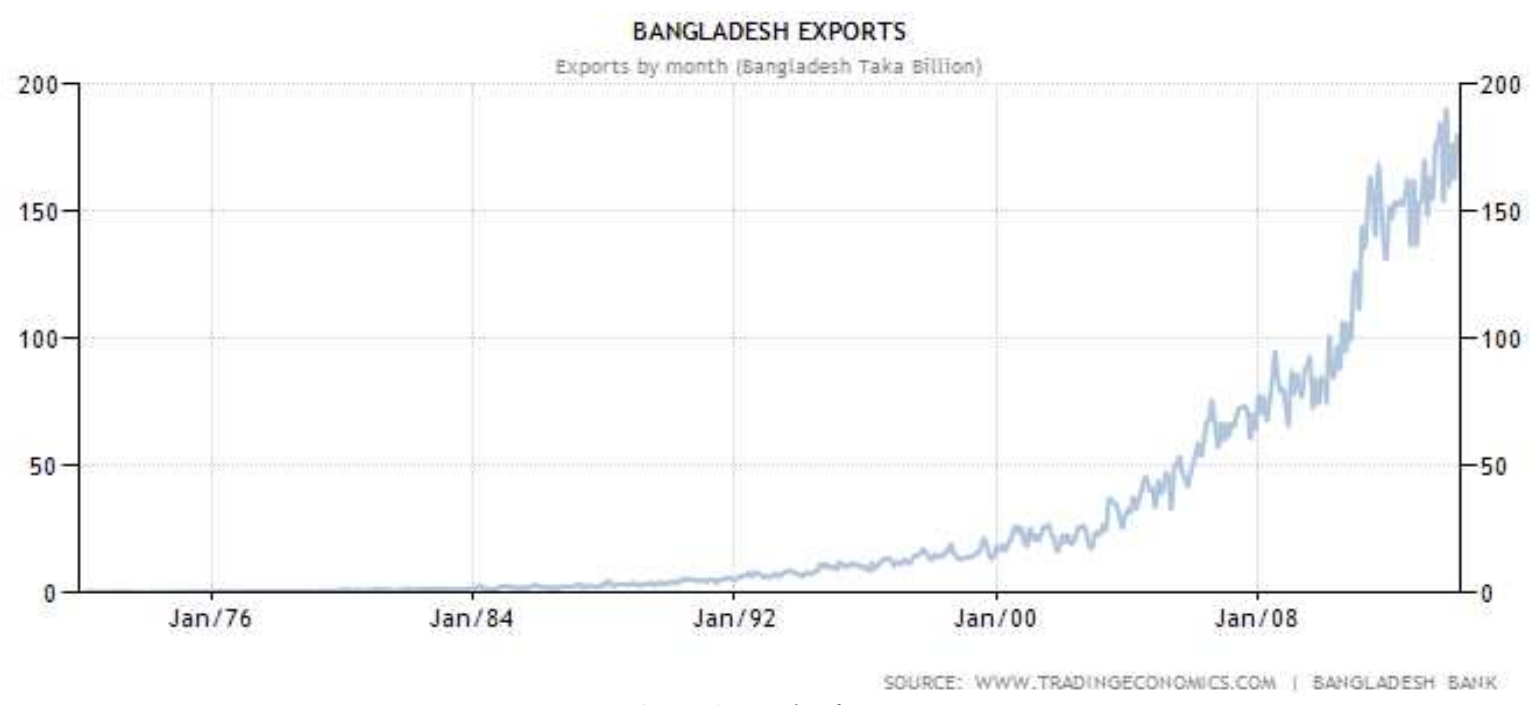

Figure 6. Trends of Export

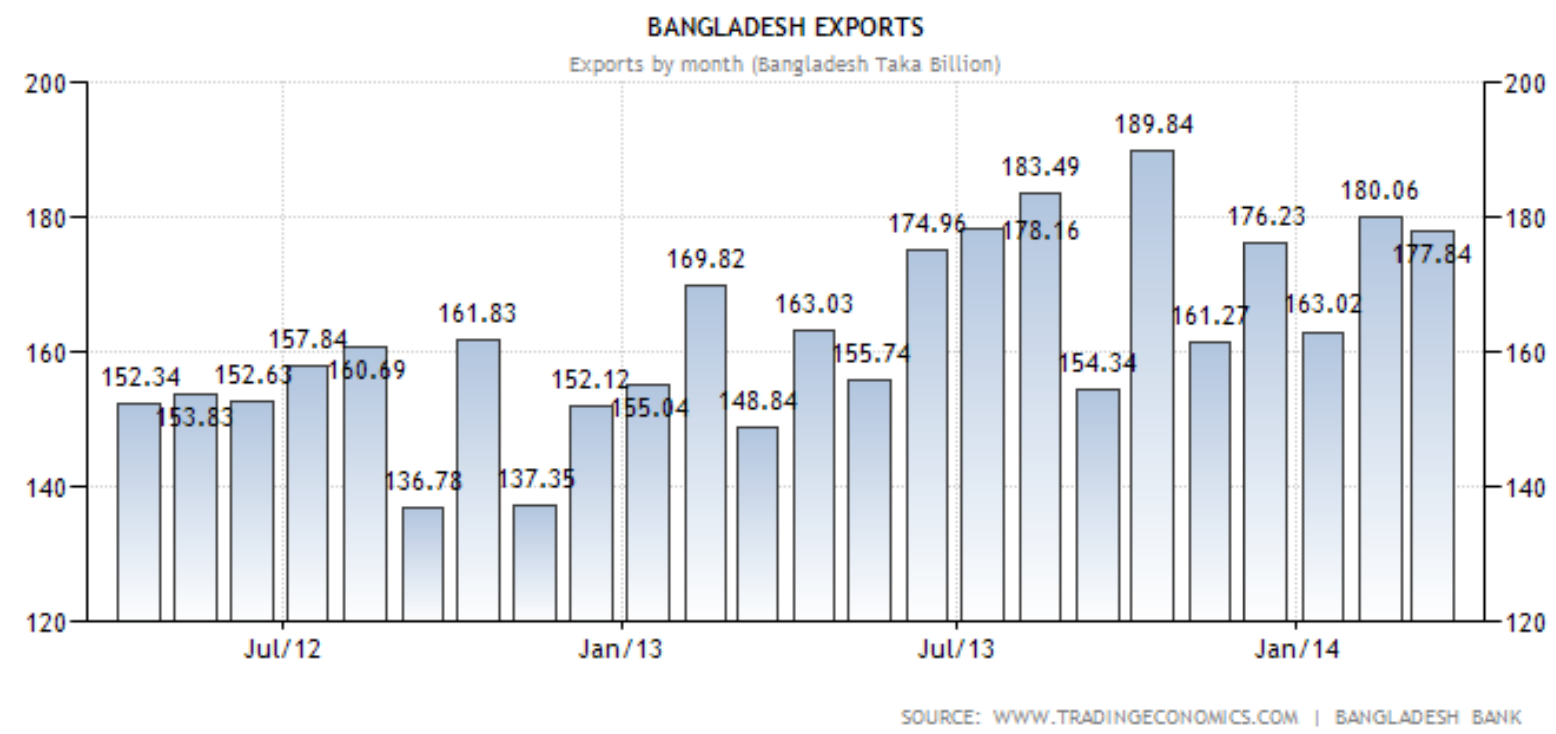

Figure 7. Trends of Export(From 2012- January 2014)

\subsubsection{Balance of Trade}

Historically, from 1995 until 2012, Bangladesh Balance of Trade averaged -1238.36 USD Million reaching an all time high of -56.40 USD Million in August of 2009 and a record low of -5370.60 USD Million in June of 2008. Bangladesh exports mainly ready made garments including knit wear and hosiery ( $75 \%$ of exports revenue). Others include: Shrimps, jute goods (including Carpet), leather goods and tea. Bangladesh main exports partners are United States (23\% of total), Germany, United Kingdom, France, Japan and India. Bangladesh imports mostly petroleum product and oil, machinery and parts, soyabean and palm oil, raw cotton, iron and steel and wheat. Bangladesh main imports partners are China (17\% of total), India, Indonesia, Singapore and Japan. This page includes a chart with historical data for Bangladesh Balance of Trade. Throughout the 1990s, the import sector of Bangladesh registered an average growth rate of about 11 per cent. During the first half of the decade, liberalization policy taken by the governments for swelling imports gave support to the flow of inputs for export-oriented and domestic industries, and led to a surge in consumer and non-production related imports. The increase in trade deficit of Tk. 1,16,051 million over 2006-07 occurred due to a larger increase in import payments (Tk. 2,65,600 million) as compared to that in export receipts (Tk. 1,49,549 million). Trade balance recorded a lower deficit of US\$3328 million during July February, 2009 - 10 compared to the deficit of US\$3581 million during July - February, 2008 - 09. Due to larger current transfers of US\$7693 million current account balance recorded a surplus of US\$2541 million during July February, 2009 - 10 against the surplus of US\$763 million during July - February, 2008 - 09. The overall balance showed a surplus of US\$2391 million during July - February, 2009 - 10 against the surplus of US\$419 million during July February, 2008 - 09. Balance of Trade in Bangladesh decreased to -1076.01 USD Million in August of 2012 from 396 USD Million in July of 2012. -Balance of Trade in 
Bangladesh averaged -19.16 Bangladesh Taka Billion from 1976 until 2014.

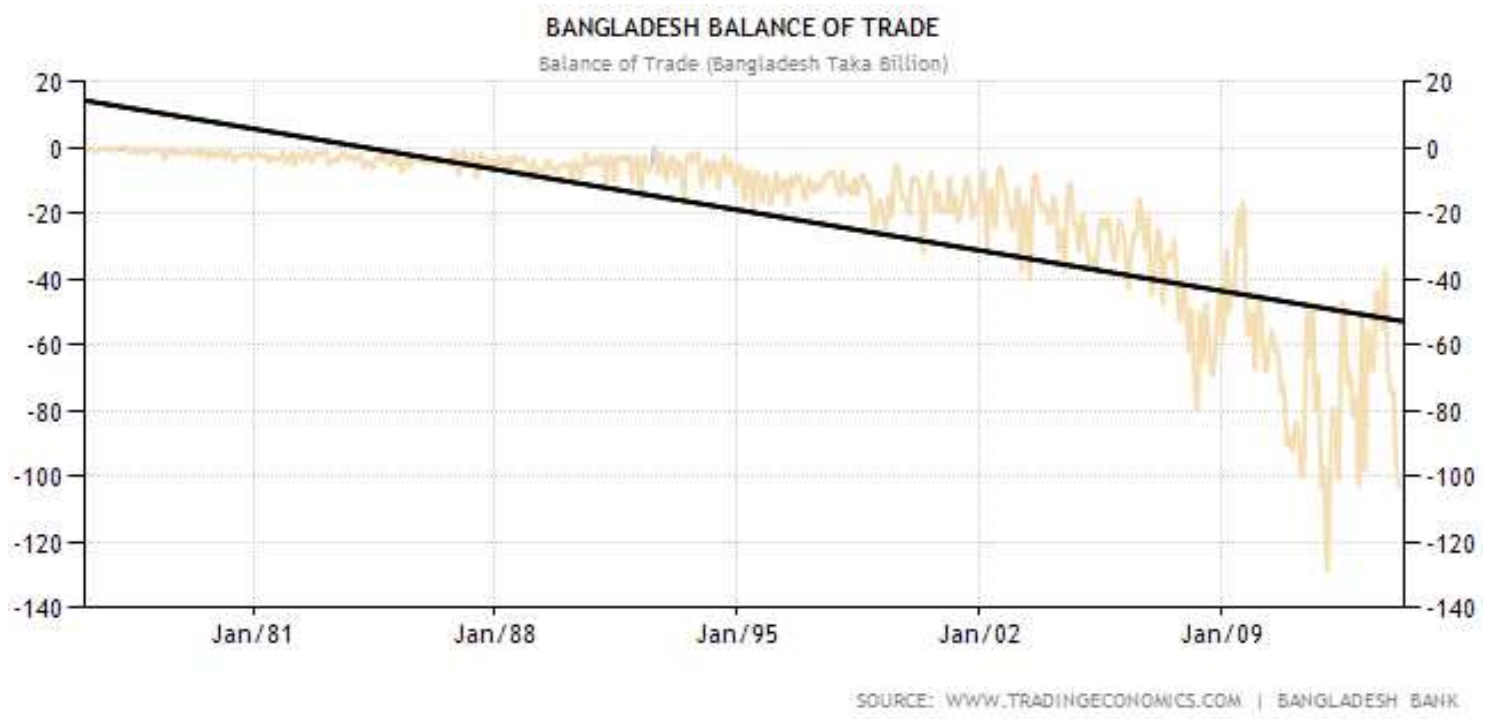

Figure 8. Trends of Balance of Trade

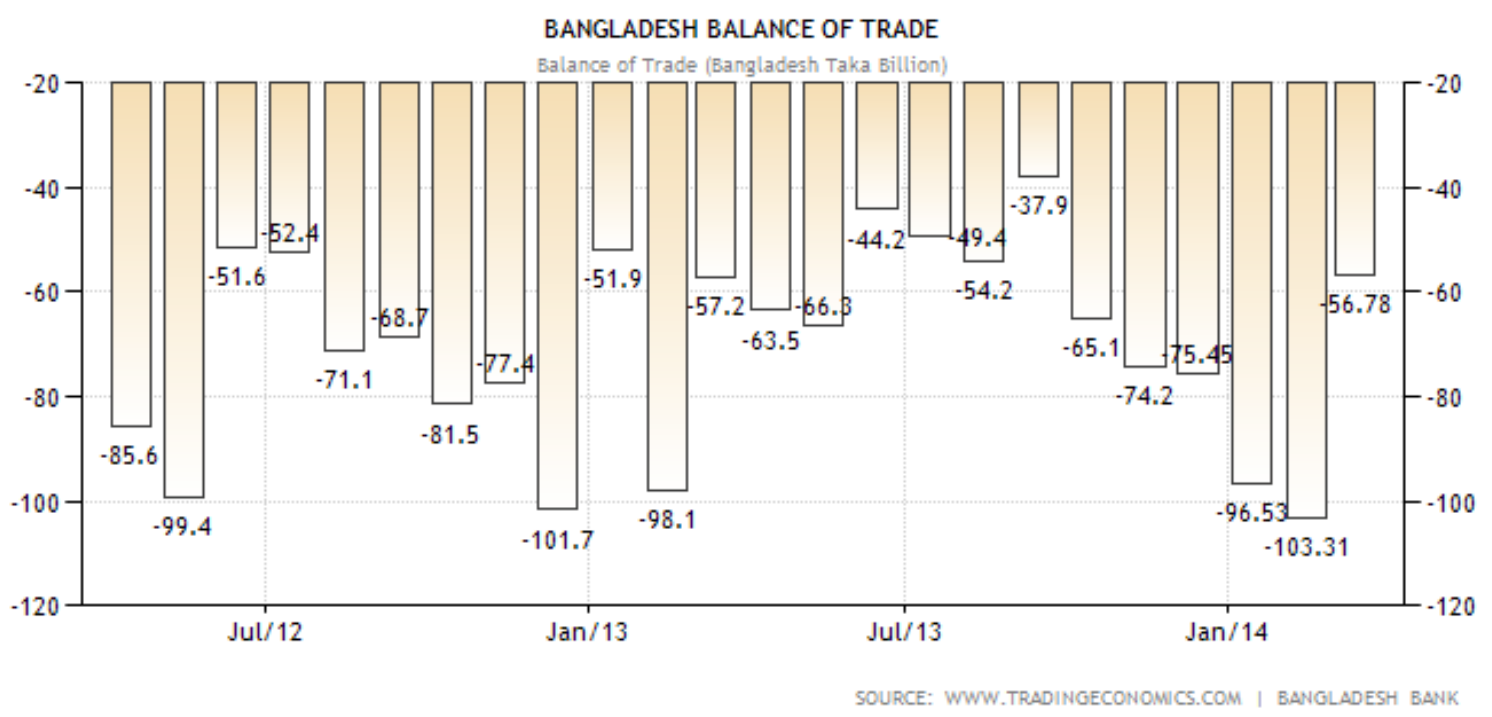

Figure 9. Trends of balance of trade (from 2012-january 2014)

\subsubsection{Remittance, Inflation and GDP}

In FY 2010-2011, migrant citizens of Bangladesh sent $\$ 11,650.30$ million as remittance that is $11.12 \%$ of GDP. According to the World Bank, Bangladesh is the $7^{\text {th }}$ largest economy of remittance receiver in the world in FY 20102011. In FY 2010-2011, the growth rate of remittance is $9.04 \%$ while the growth rate of GDP remains at $6.66 \%$ and rate of inflation increases to $8.8 \%$. In FY 2010-2011, the food inflation is $10.65 \%$ and nonfood inflation is only $3.92 \%$. The GDP of the country is decreasing due to inflation and decrease of remittance receipt. In Table 1, we display GDP and Remittance as a percentage share of GDP from fiscal year 2001-2002 to 2014-2015.

In Bangladesh major portion of the remittance spends to buy food and basic consumption goods, housing, children's education and health care. A total of $43 \%$ of remittance receipt is spent on food consumption nationally while only
$19.2 \%$ is spent on cash savings, $6.4 \%$ on investment in business. As a result, higher growth rate of remittance may induce the rate of inflation.

\subsection{Debts and Deficit in Bangladesh}

In Bangladesh, there are two sources of deficit financing: i) internal debt, and ii) external debt. The government mainly borrows both from the Bangladesh Bank and the commercial banks. In FY 2001-2002, government has borrowed an amount of Tk.2,534.9 crore from banking sector and Tk.4,711.47 crore $(1$ crore $=10,000,000)$ from non-banking sectors. In FY 2010-2011, the government has borrowed Tk.11,240.5 crore from banking sectors, which is 4.43 times higher than that of FY 2001-2002.

The public debt of Bangladesh is increasing continuously, which is creating serious pressure on the macroeconomic stability of the country. The government borrowing from 
banking sector in FY 2010-2011 was $1.43 \%$ of GDP while it was $0.45 \%$ from non-banking sectors. Total debt of Bangladesh in FY 2010-2011 is $\$ 23,322.417$ million that is $22.21 \%$ of GDP. Total domestic debt in FY 2010-2011 is $\$ 1,974.97$ million that is $1.88 \%$ of GDP. Total domestic borrowing as percentage of GDP remains 1.5 to $3.0 \%$ of GDP over the last ten years. In FY 2010-2011, total external debt of Bangladesh amounts to $\$ 21,347.44$ million that is $20.24 \%$ of GDP. The government may have to borrow Tk.17,755.76 crore from domestic sources and $\$ 23,475.68$ million as external debt in FY 2014-2015 (Bangladesh Economic Update, 2011b). The per capita debt burden in FY 2010-2011 in Bangladesh has increased by $8.41 \%$ over that of FY 20092010 (\$151). Per capita debt burden in Bangladesh in FY 2010-2011 is \$163 and in FY 2014-2015 it might increase to $\$ 171.83$, an increase of $5.42 \%$ per annum. In FY 2014-2015, the per capita domestic and outstanding debt might be $\$ 15.79$ and $\$ 156.03$ respectively against per capita domestic debt of $\$ 13.87$ and outstanding external debt of \$149.99 in FY 20102011 (Bangladesh Economic Update, 2011b). Each year the government has to borrow from domestic and external sources to cover the budget deficit, and each year a major portion of its budget expenditure gets expanded on interest payment. In case of non development (interest, social security and welfare, and subsidies) expenditure, usually the highest allocation goes to interest payment. In FY 2006-2007, the interest payment has been $17 \%$ of its total nondevelopment expenditure while social security and welfare and subsidies have got an allocation of only 4 and $5.4 \%$ of its non-development expenditure respectively. In FY 2009- 2010, $19.2 \%$ of total non-development expenditure has been spent for interest payment, and FY 2011-2012 it was about 15.5\%
(Bangladesh Economic Update, 2011b). Total debt-GDP ratio in Bangladesh, on average, rose sharply from $33.65 \%$ during the 1970 s to $56.95 \%$ during the 1980 s. Over the last ten years, the debt-GDP ratio has stayed above $40 \%$ and that reflects the high debt burden for Bangladesh. The debt-GDP ratio in FY 2010- 2011 has reached at 41\% (Bangladesh Economic Update, 2011b). Total external debt in FY 2010-2011 is \$21,347.44 million while in FY 1972-2013 it was only \$65 million. Over the time the amount of external debt has been increasing at a higher rate. In FY 2010-2011, the external debt and GDP ratio has remained at 23.1 against 30.4 in FY 2000-2001. These figures indicate that the external debt and GDP ratio has declined over time. On the other hand in FY 2010-2011, domestic and outstanding external debt burden ratio is $0.092: 1$. The debt burden ratio might increase further in FY 2014-2015 to outstanding external debt of Tk.100 against domestic debt of Tk.10.10. Hence, the government of Bangladesh is highly dependent on external debts and in forthcoming years, domestic debt burden might increase further.

Bangladesh recorded a Government Budget deficit equal to 4.5 percent of the country's Gross Domestic Product in the fiscal year 2011/2012. From 1994 until 2012, Bangladesh Government Budget averaged -3.3 Percent of GDP reaching an all time high of -1.6 Percent of GDP in December of 2009 and a record low of -5.3 Percent of GDP in December of 2008. Government Budget is an itemized accounting of the payments received by government (taxes and other fees) and the payments made by government (purchases and transfer payments). A budget deficit occurs when an government spends more money than it takes in. The opposite of a budget deficit is a budget surplus.

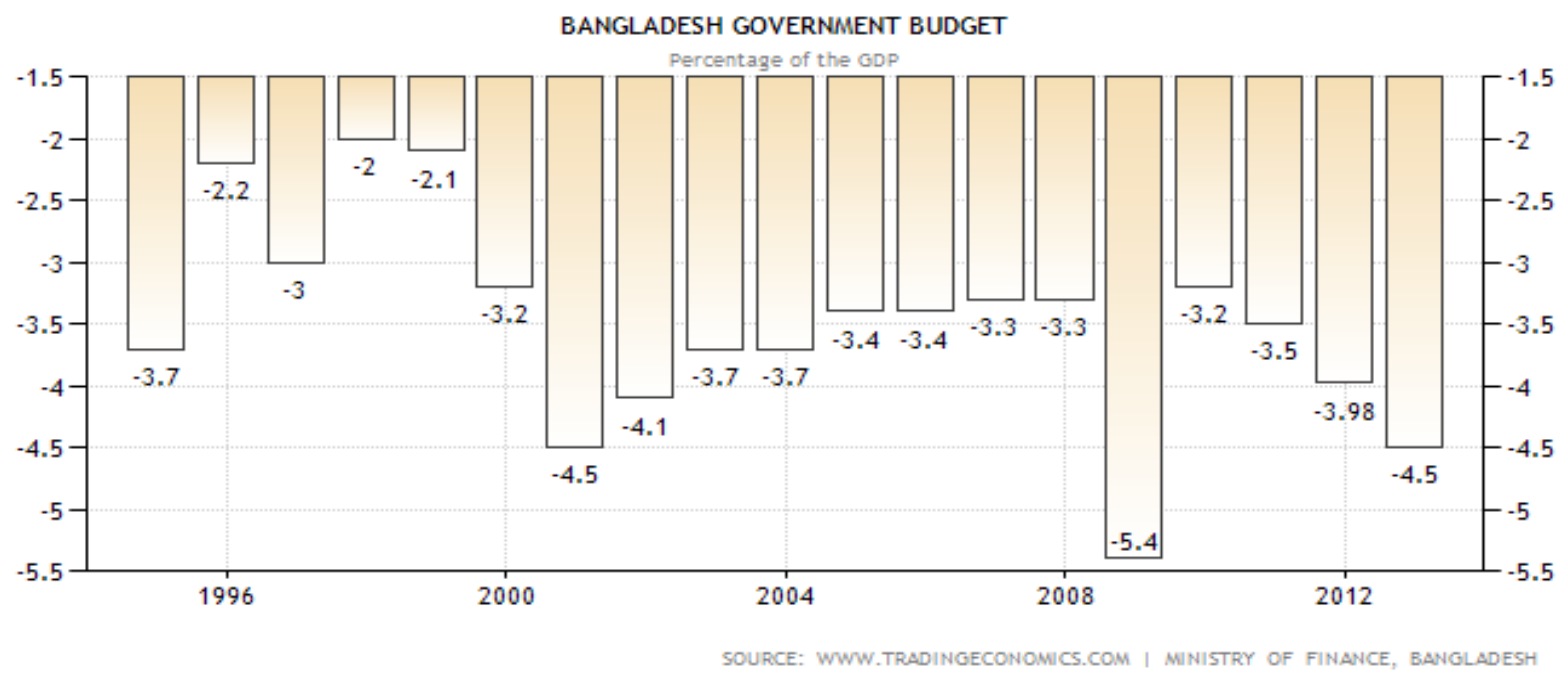

Figure 10. Size of Government Budget

\subsection{Collapse of the Capital Market}

In Bangladesh, price fluctuation in the capital market has become a major concern of many investors nowadays. Investors both institutional and individual are affected by the price fluctuation. Price fluctuation may occur both in up and down direction. An upside fluctuation may offer profit to investors while a down side fluctuation may cause significant amount of risk to investors. For this reason, investors are trying to devise out mechanisms to forecast the direction and magnitude of price fluctuation. Over the past few years, the share market has been experiencing a rapid growth. The 
market turnover and volume of trading have broken the previous records recently. In this situation, the market authority became worried that the 1996 incident would be repeated. The crash in equity market happened since 2011 and until 2013 it remains in crash position. Widespread reports of malpractice terminated in a domestic capital market crisis in 1996 and in 2011. As a result, at present the confidence of the investor is low. Changes in political commitment, a difficult political economy, and weak institutional capacity of executing agencies often frustrate implementation of financial sector assistance. The capital market has a low level of supervision and the major market players, such as capital exchanges, brokers, dealers, and asset managers have limited professional capacity. Transparency is poor and there is inadequate disclosure both in trading and in the quality of information provided for listed companies. It is seen in recent times that capital markets of our country has been undergoing heavy fluctuation. The frequency and magnitude of price fluctuation in the capital market is also quite high what causes individual investors to lose their capital that ultimately result in losing their confidence in the market system. If this difficulty continues for long time the market will lose its participants and trading volume will also go down significantly. Chowdhury (1995) explains the lack of efficiency in the emerging capital markets by investigating the issue of informational efficiency in the Dhaka Stock Exchange (DSE) in Bangladesh. He argued that in an efficient market the prices of the securities fully reflect all available information; that is, capital market participants incorporate the information contained in money supply changes into stock prices. Some investors feel that inefficiency of the regulatory body is responsible for the recent fall in the equity market. The large number of investors point out gambling being the main reason for the current downturn in the market. Few investors think that liquidity crisis and multi level marketing (MLM) business has also contributed to the downturn. The opinions of the investors are given in Figure 1 as shown below:

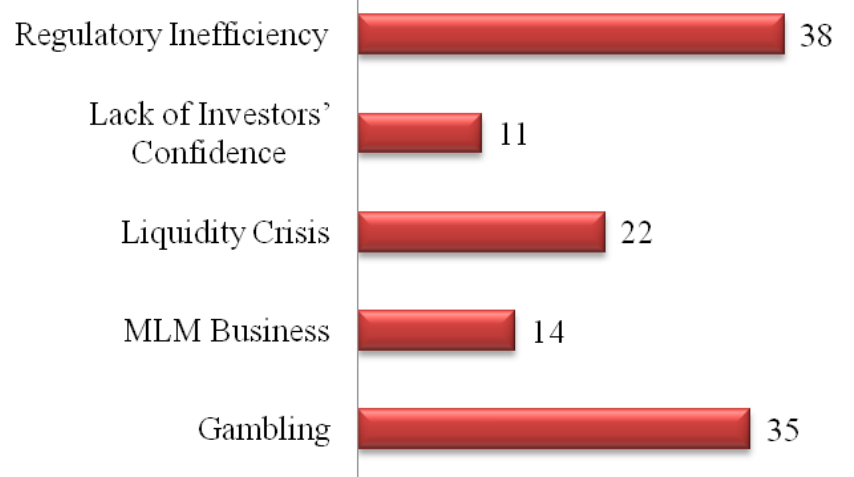

Figure 11. Opinion of reason of current capital market crash.

Almost $53 \%$ of the investors are of the opinion that there prevails a strong political collusion behind the collapse in the stock market (Figure 2), 23\% of them; however, do not agree with this decision. About $24 \%$ of the investors remain indifferent about political motivations as depicted below:

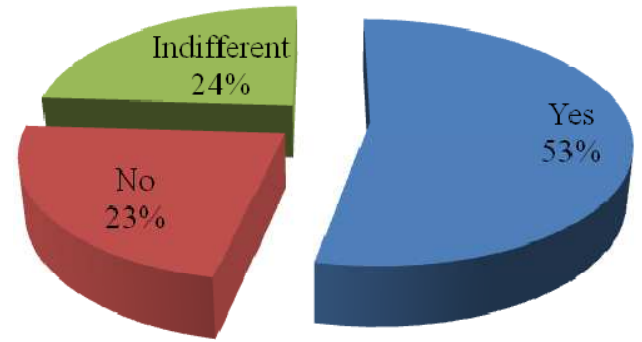

Figure 12. Opinion of reason of current capital market crash (view in Pie Chart)

Price fluctuation in the capital market has become a major concern of many investors since 2010. Investors; both institutional and individual, are affected by the price fluctuation. For this reason, investors are trying to devise out mechanisms to forecast the direction and magnitude of price fluctuation. The Securities and Exchange Commission has withdrawn the weighted average index from Dhaka and Chittagong Stock Exchanges for its failure to reflect the fluctuation of price of securities traded on the stock exchanges.

\section{Recommendations \& Conclusions}

In this paper we have tried to discuss aspects of economic development of Bangladesh. Bangladesh is developing step by step and we hope that within the $21^{\text {st }}$ century the country will reach in peak of the development. The migrated labors are sending remittance from abroad but all of them are not using the economic development. Production of electricity and gas supplies in industries, construction of roads, bridges and development of ports, and political stability are necessary for the economic development. Inflation in all the commodities is a great problem of the economic development. Government must stress on creating efficient manpower and national production should be increased. Bangladesh is a small country but its natural resources are rich and these must be used properly. Government and social organizations must take various steps to improve education and make the large populations as boon not burden of the country. Government should increase the fund in annual budget in education sector. At present the government budget for higher education is very low and it should be increased to create intellectual persons. The government of Bangladesh should follow the strategy of Japan. Japan has no huge natural resources, such as, mines, forests etc. as like other developed countries but it becomes a developed country due to its educated and skilled populations.

Government should take strong steps to stop corruption. Bangladesh was in top in corruption in the world for consecutive five years in the last decade. At present the corruption has partially decreased and we hope the government of Bangladesh will be more active to oust corruption completely. Political unrest is a great problem of the country. Due to political instability foreign direct 
investment is not satisfactory in Bangladesh. The country has two seaports and many rivers for transport and most portion of the country is plane. Hence communication is not very costly and it is a natural advantage for the country in the way of development. Government should take steps to decrease domestic and foreign debts to reduce payment of interest. The budget deficit should be decreased to reduce debts. Subsidies in non-productive sectors must be decreased step by step. The government should export skill labors to earn more remittance and skill labors must be created with various training programs.

\section{References}

[1] Ahmed I, Farah QF, Salahuddin N, Chowdhury MI (2009). Inflationary trend in Bangladesh and impact on high food commodity prices, Unnayan Onneshan (The Innovators), Economic Policy Unit (EPU), Bangladesh.

[2] Bangladesh Bureau of Statistics (BBS) (2007). Yearbook of agricultural statistics, Bangladesh.
[3] Bangladesh Economic Update (2011a). Food prices and inflation trajectory, Economic Policy Unit, Unnayan Onneshan (The Innovators), 2(1):1-12.

[4] Bangladesh Economic Update (2011b). Deft and deficit, Economic Policy Unit, Unnayan Onneshan (The Innovators), 2(7):1-25.

[5] Bangladesh Economic Update (2011c). Remittance, Unnayan Onneshan (The Innovators), 2(8):1-21.

[6] Chowdhury AR (1995). Is the Dhaka Stock Exchange informationally efficient? The Ban. Dev. Stu. XXIII:89-104.

[7] Household Income and Expenditure Survey, HIES (2010). Preliminary report on household income and expenditure survey: statistics division, Ministry of Planning, The Government of the People's Republic of Bangladesh.

[8] Islam JN, Mohajan HK, Datta R (2012). Aspects of microfinance of Grameen Bank of Bangladesh, Int. J. Eco. and Res. 3(4): 76-96. 